\title{
SISTEM PENGENDALIAN RISIKO OPERASIONAL PADA BANK PERKREDITAN RAKYAT DENGAN PENDEKATAN INDIKATOR DASAR
}

\author{
Sunarjo ${ }^{1}$, Sari Yuniarti ${ }^{2}$ \\ ${ }^{1}$ Fakultas Hukum Universitas Merdeka Malang \\ ${ }^{2}$ Program D-III Perbankan dan Keuangan Universitas Merdeka Malang \\ JL. Terusan Raya Dieng No.62-64 Malang, 65146, Indonesia
}

\begin{abstract}
:
Keywords:

Basic Indicator

Approach, Capital

Charge, Operational

Risk, Rural Bank

JEL Classification: G21, G31, G34

$B P R$ as the micro financial medium institution was seen as one of translation media and risk transformation. The ability of BPR in managing risk became an attention along with the increase of volume and the business operational complexity, including bank operational risk like fraud caused by people, system, or external condition. If there was no controlling, it would create loss potency for BPR itself. This research aimed to measure the loss effect because of operational risk and to identify the system of operational risk control using basic indicator approach. The population of this research was all BPR in Malang, namely 39 banks. The samples used were 20 banks. Data collection method used was observation and documentation. The research result showed that operational risk events were divided into 4 quadrants, namely Low Frequency/High Impact, High Frequency/High Impact, Low Frequency/Low Impact, and High Frequency/Low Impact. The quadrants division resulted information related to how the operational risk would be managed. Total capital charge of all BPR in Malang was IDR.4.085.114.000,00. It indicated that the total capital charge used was to anticipate the operational risk.
\end{abstract}

Kata kunci:

Pendekatan

Indikator Dasar,

Biaya Modal,

Risiko

Operasional, BPR

\begin{abstract}
Abstrak:
BPR sebagai lembaga perantara keuangan mikro, semakin dilihat sebagai salah satu media translasi dan transformasi risiko. Kemampuan BPR dalam mengelola risiko semakin menjadi perhatian sejalan dengan peningkatan volume dan kompleksitas operasional bisnisnya, termasuk risiko operasional bank seperti fraud yang disebabkan oleh orang, sistem atau kondisi eksternal, yang apabila tidak dilakukan pengendalian menciptakan potensi kerugian bagi BPR yang bersangkutan.Penelitian ini bertujuan untuk mengukur dampak kerugian yang ditimbulkan akibat adanya risiko operasional dan mengidentifikasi sistem pengendalian risiko operasional dengan menggunakan pendekatan indikator dasar. Populasi dalam penelitian ini adalah seluruh BPR di Kota dan Kabupaten Malang yang berjumlah 39 bank. Sampel yang digunakan sebanyak 20 bank. Metode pengumpulan data dengan menggunakan observasi dan dokumentasi. Hasil penelitian menunjukkan kejadian risiko operasional terbagi dalam 4 kuadran yaitu: Low Frequency/High Impact, High Frequency/High Impact, Low Frequency/Low Impact, dan High Frequency/Low Impact. Pembagian kuadran tersebut menghasilkan informasi yang terkait dengan bagaimana risiko operasional akan dikelola. Total capital charge seluruh BPR di Wilayah Malang sebesar Rp.4.085.114.000,00, hal ini menunjukkan besar jumlah capital charge yang digunakan untuk mengantisipasi terjadinya risiko operasional.
\end{abstract}


Risiko operasional sebenarnya lazim dihadapi berbagai lembaga keuangan termasuk bank, namun jenis risiko ini baru mendapatkan perhatian luas setelah dimasukan ke dalam kerangka regulasi Basel II. Mencermati akar permasalahan krisis yang ada maka dirasakan kebutuhan untuk menyempurnakan kembali kerangka permodalan yang ada (Basel II) dan dari pembahasan di berbagai fora internasional (G20, Financial Stability Board/FSB dan Basel Committee on Banking Supervision/BCBS), kerangka Basel III pada akhirnya menjadi inisiatif baru. Sesuai dengan substansi, Basel III secara mendasar menyajikan reformasi yang dilakukan oleh BCBS untuk memperkuat permodalan dan standar likuiditas dengan tujuan untuk meningkatkan ketahanan sektor perbankan terhadap krisis (Bank Indonesia, 2012). Kemampuan sektor perbankan menyerap shock yang terjadi karena tekanan keuangan dan perekonomian diharapkan dapat mengurangi penyebaran risiko dari sektor keuangan terhadap perekonomian.

Manajemen risiko yang terkait dengan risiko operasional ini dikenal sebagai manajemen risiko operasional. Seiring dengan itu, terdapat kebutuhan akan pemahaman yang memadai dan komprehensif mengenai manajemen risiko operasional. Risiko operasional merupakan risiko yang memengaruhi semua kegiatan usaha karena merupakan suatu hal yang inherent dalam pelaksanaan suatu proses atau aktivitas operasional (Bhatia, 2002). Risiko operasional didefinisikan oleh Basel Committee on Banking Supervision (2004) sebagai risiko kerugian akibat kurang memadainya atau gagalnya proses internal, yang disebabkan oleh orang dan sistem atau kejadian eksternal, yang termasuk di dalamnya risiko hukum, di luar risiko strategis dan reputasi.

Risiko operasional sangat terkait dengan banyaknya masalah yang timbul karena kelemahan proses didalam BPR. Namun demikian risiko operasional tidak hanya terdapat pada bank saja, tetapi pada setiap jenis usaha. Risiko operasional merupakan risiko yang penting yang dapat me- mengaruhi nasabah secara harian. Itu sebabnya mengapa bank meningkatkan fokus perhatiannya pada proses, prosedur dan pengawasan yang sejalan dengan risiko operasional. Berbagai bentuk risiko operasional, seperti penipuan dan penggelapan, telah dikelola secara aktif oleh BPR melalui $\mathrm{SDM}$, pengendalian, dan sistem keamanan yang digunakan bank. Pada Pilar 1 Basel II Capital Accord bank dipersyaratkan untuk mengkuantifikasi dan mengalokasikan kebutuhan modal sesuai ketentuan untuk mengantisipasi potensi kerugian risiko operasional (Hawke, 2002). Bagi otoritas pengawas bank, penerapan manajemen risiko akan mempermudah penilaian terhadap kemungkinan kerugian yang dihadapi bank yang mempengaruhi permodalan bank dan sebagai salah satu dasar penilaian dalam menetapkan strategi dan fokus pengawasan bank. Adapun tahap evolusi manajemen risiko operasional dibagi menjadi empat bagian tahap (Ebnöther et al., 2001).

Tahap identifikasi dan pengumpulan data. Pada tahap ini perusahaan perlu melakukan mapping berbagai risiko operasional yang ada dalam perusahaan dan menciptakan suatu proses untuk mengumpulkan data dan menjumlahkan kerugian. Tahap penyusunan metrics dan tracking. Dalam tahap ini perusahaan perlu menyusun metric dan key risk indicator untuk tiap risiko operasional yang telah diidentifikasi dalam tahap sebelumnya, termasuk juga penyusunan sistem tracking data dan informasi frekuensi dan severitas suatu risiko tertentu (Scandizzo, 2005). Tahap pengukuran. Tahap ini perusahaan perlu menyusun suatu metode untuk mengklasifikasi risiko operasional dari semua unit kerja. Tahap manajemen. Tahap ini perusahaan perlu melakukan konsolidasi hasil dari tahap tiga untuk mendapatkan perhitungan alokasi modal untuk menutup risiko operasional dan analisis kinerja berbasis risiko dan redistribusi portofolio untuk menyesuaikan profil risiko perusahaan yang diinginkan.Tujuan dari manajemen risiko operasional adalah meyakinkan bahwa risiko operasional yang dihadapi perusahaan dapat diidenti- 
fikasi, diukur, dikendalikan, dan dilaporkan dengan benar melalui penerapan kerangka manajemen risiko (strategi, organisasi, kebijakan dan pedoman serta infrastruktur) yang sesuai. Menurut Moosa (2011) bahwa manajemen risiko operasional memiliki tujuan mengubah inherent risk (risiko yang melekat) yang terdapat dalam aktivitas organisasi menjadi residual risk dan mengelola penyebab timbulnya risiko operasional, sehingga dapat menekan atau mencegah timbulnya risiko yang mengakibatkan potensi kerugian operasional perusahaan. Dengan penerapan manajemen risiko operasional maka perusahaan diharapkan mampu mengelola potensi kerugian untuk mengoptimalkan pendapatan bank, mengurangi volatilitas pendapatan, meningkatkan risk awareness, memaksimalkan nilai asset pemegang saham (shareholder dan stakeholder value) melalui pengembangan infrastruktur, budaya dan manajemen, serta memperbesar peluang kerja dan jaminan finansial (Lenzmann, 2005).

Proses manajemen risiko operasional merupakan tindakan dari seluruh entitas terkait dalam organisasi. Tindakan berkesinambungan yang dilakukan sejalan dengan definisi manajemen risiko, yaitu proses identifikasi, pengukuran risiko, pemantauan dan pengendalian risiko. Menurut Pyle (1997) kejadian risiko operasional dapat dikelompokkan kedalam empat jenis kejadian berdasarkan frekuensi dan dampak risiko operasional tersebut, yaitu: (1) Low Frequency/High Impact (LFHI); (2) High Frequency/High Impact (HFHI); (3) Low Frequency/Low Impact (LFLI); dan (4) High Frequency/Low Impact (HFLI)

Secara umum pengelolaan risiko operasional memfokuskan pada dua jenis kejadian, yaitu Low Frequency/High Impact (LFHI) dan High Frequency/ Low Impact (HFLI). LFHI sangat sulit untuk dipahami dan sangat sulit untuk diantisipasi serta LFHI menimbulkan kerugian yang sangat besar bahkan dapat menyebabkan kejatuhan suatu bank.
Sedangkan HFLI dikelola untuk meningkatkan efisiensi kegiatan usaha.

Pendekatan Indikator Dasar (Basic Indicator Approach) adalah pendekatan yang digunakan untuk melakukan perhitungan beban modal risiko operasional (Sundmacher, 2007). Bank yang menggunakan pendekatan ini wajib menerapkan prinsipprinsip manajemen risiko operasional yang baik sesuai dengan ketentuan Bank Indonesia. PID ini diarahkan agar bank secara rata-rata dapat mempertahankan $12 \%$ dari jumlah regulator capital-nya untuk menampung kemungkinan kerugian sebagai akibat dari risiko operasional. Target $12 \%$ ini didasarkan pada suatu survei yang mengungkapkan bahwa hal itu telah dilakukan secara internasional oleh bank-bank besar, sedangkan pada BPR target tersebut dapat mencapai 12,5\% (Otoritas Jasa Keuangan, 2015). Menurut BIS suatu bank yang mempertahankan suatu fraction (alpha) tertentu dari gross income-nya bagi operational risk capital akan dapat men-generate cukup modal untuk menampung kerugian akibat risiko operasional. Menurut perhitungan itu, bila alpha $(\alpha)$ diperhitungkan sebesar 15\% maka bank akan dapat men-generate cukup modal bagi risiko operasional hingga sebesar $12 \%$ dari jumlah regulatory capital-nya itu.

Penelitian ini bertujuan untuk mengukur dampak kerugian yang ditimbulkan akibat adanya risiko operasional dan mengidentifkasi sistem pengendalian risiko operasional dengan menggunakan pendekatan indikator dasar.

\section{METODE}

Berdasarkan tujuan yang dipelajari, penelitian ini termasuk penelitian deskriptif kualitatif. Penelitian deskriptif bertujuan untuk memperoleh gambaran tentang parameter yang diukur. Penelitian deskriptif adalah penelitian yang dilakukan untuk mengetahui nilai variabel mandiri, baik satu variabel atau lebih (independen) tanpa membuat perbandingan, atau menghubungkan dengan 


\section{Sistem Pengendalian Risiko Operasional pada Bank Perkreditan Rakyat dengan Pendekatan Indikator Dasar Sunarjo, Sari Yuniarti}

variabel yang lain (Sugiyono, 2008). Populasi dalam penelitian ini adalah seluruh BPR di Malang yang berjumlah 39 bank (Publikasi Laporan Bank Indonesia Malang, 2014). Teknik pengambilan sampel menggunakan proportional random sample, dimana masing-masing BPR di Kota dan Kabupaten Malang diambil 50\% dari jumlah BPR. Jumlah BPR Kota Malang sebanyak 7 bank (sampel 4 bank) dan BPR di Kabupaten Malang sebanyak 32 bank (sampel 16 bank), sehingga total jumlah sampel 20 bank. Data primer diperoleh peneliti dari responden, yaitu Pimpinan/Dirut BPR-BPR di wilayah Kota dan Kabupaten Malang, melalui wawancara dan pengisian kuesioner.

\section{Teknik Analisis}

\section{Analisis Kejadian Risiko Operasional}

Analisis ini berkaitan dengan mapping kejadian risiko operasional, yang dapat dikelompokkan kedalam empat jenis kejadian berdasarkan frekuensi dan dampak risiko operasional tersebut, yaitu: (1) Low Frequency/High Impact (LFHI); (2) High Frequency/High Impact (HFHI); (3) Low Frequency/ Low Impact (LFLI); (4) High Frequency/Low Impact (HFLI)

\section{Pendekatan Indikator Dasar (Basic Indicator Approach)}

Pendekatan Indikator Dasar digunakan dalam melakukan perhitungan beban modal (capital charge) risiko operasional. Bank yang menggunakan pendekatan ini wajib menerapkan prinsip-prinsip manajemen risiko operasional yang baik sesuai dengan ketentuan Bank Indonesia. Untuk menghitung potensi kerugian operasional dengan pendekatan Basic Indicator Approach digunakan rumus sebagai berikut:

$$
K_{B I A}=\frac{\sum\left(G I_{123} \times \alpha\right)}{n}
$$

Keterangan:

$$
\begin{aligned}
\mathrm{K}_{\mathrm{BIA}}= & \text { modal risiko operasional yang dipersya- } \\
& \text { ratkan berdasarkan BIA } \\
\mathrm{GI}= & \begin{array}{l}
\text { gross income tahunan selama tiga tahun ter- } \\
\text { akhir yang bernilai positif }
\end{array} \\
\alpha= & 15 \% \\
\mathrm{n}= & \text { jumlah tahun dalam tiga tahun terakhir } \\
& \text { dimana gross income bernilai positif }
\end{aligned}
$$

\section{HASIL}

\section{Hasil Mapping Score Kejadian Risiko Operasional BPR-BPR di Wilayah Malang}

Hasil identifikasi kejadian risiko operasional tersebut didasarkan pada pertimbangan dan data pendukung di BPR-BPR. Untuk keperluan mapping, maka kejadian risiko operasional dilakukan penilaian/score untuk mengetahui frekuensi terjadinya risiko (frequency) dan dampak dari risiko bagi operasional bank (impact). Penilaian tersebut menggunakan nilai interval 1-10 yang dilakukan oleh BPR. Hasil penilaian tersebut dicari nilai ratarata, dan digunakan sebagai dasar penilaian masingmasing kejadian risiko operasional. Adapun hasil penilaian/score rata-rata kejadian risiko operasional ditunjukkan pada Tabel 1.

Berdasarkan hasil rata-rata score kejadian risiko operasional tersebut, maka selanjutnya dilakukan mapping/pemetaan. Adapun langkah-langkah mapping adalah: (1) menggambar sumbu horizontal $\mathrm{X}$ yang menunjukkan frekuensi terjadinya risiko operasional dan sumbu vertikal $Y$ yang menunjukkan tingkat impact adanya risiko operasional. (2) membuat garis potong/bantu yang memisahkan dimensi kejadian risiko operasional dalam 4 kuadran, dimana kedua garis rata-rata ditarik dari nilai rata-rata frekuensi $(X=4,5)$ dan nilai ratarata tingkat impact $(\mathrm{Y}=6,3)$ yang menjadi titik perpotongan diagram $(4,5 ; 6,3)$, kemudian (3) membuat rata-rata masing-masing score kejadian diplot dalam scater diagram. Hasil mapping ditunjukkan pada Gambar 1. 
Berdasarkan Gambar 1 dapat diketahui bahwa kejadian risiko operasional terbagi dalam 4 kuadran. Pembagian kuadran tersebut menghasilkan informasi yang terkait dengan bagaimana risiko tersebut akan dikelola. Adapun interpretasi dari pembentukan kuadran-kuadran tersebut dijelaskan sebagai berikut.
Kuadran I berisi kejadian yang memiliki tingkat frekuensi terjadi risiko rendah dan tingkat impact yang rendah, hal ini menunjukkan bahwa kejadian risiko operasional ini dinilai tidak terlalu memberikan dampak kerugian dan tidak terlalu sering terjadi. Kejadian-kejadian yang termasuk dalam kuadran ini adalah: dokumentasi/arsip yang

Tabel 1. Hasil Rata-rata Penilaian/Score Berdasarkan Frekuensi dan Dampak Kejadian-kejadian Risiko Operasional di BPRBPR Wilayah Malang

\begin{tabular}{|c|c|c|}
\hline $\begin{array}{l}\text { Kejadian Risiko Operasional } \\
\end{array}$ & Frekuensi & Impact \\
\hline \multicolumn{3}{|l|}{ Risiko Proses Internal } \\
\hline - Kesalahan melakukan transaksi & 6,4 & 8,5 \\
\hline - Dokumentasi/arsip yang tidak lengkap & 4,4 & 3,4 \\
\hline - Kelalaian petugas pemasaran & 5,6 & 3,9 \\
\hline - Pengendalian intern yang lemah & 6,6 & 7,2 \\
\hline - Kesalahan dalam memberikan informasi & 4,8 & 3 \\
\hline - Laporan keuangan yang tidak lengkap atau tidak benar & 3,7 & 7,5 \\
\hline \multicolumn{3}{|l|}{ Risiko Manusia } \\
\hline - Permasalahan kesehatan dan keselamatan kerja & 2,6 & 6,8 \\
\hline - Perputaran karyawan yang tinggi & 3,1 & 5,4 \\
\hline - Penipuan internal & 5,4 & 5 \\
\hline - Sengketa antar karyawan & 3,3 & 6,3 \\
\hline - Praktek manajemen yang buruk & 9,2 & 10 \\
\hline - Pelatihan karyawan yang tidak memadai & 8,4 & 10 \\
\hline - Terlalu tergantung pada karyawan tertentu & 3,5 & 2,2 \\
\hline \multicolumn{3}{|l|}{ Risiko Sistem } \\
\hline - Data yang tidak lengkap (data corruption) & 6,5 & 5,7 \\
\hline - Kesalahan input data (data entry errors) & 5,8 & 8,8 \\
\hline - Pengendalian perubahan data yang tidak memadai & 3,7 & 4,2 \\
\hline - Gangguan pelayanan,baik gangguan sebagian/ seluruhnya & 4,2 & 6,3 \\
\hline \multicolumn{3}{|l|}{ Risiko Eksternal } \\
\hline - Pencurian dan penipuan dari luar & 2,0 & 6,8 \\
\hline - Kebakaran & 1,8 & 8,6 \\
\hline - Bencana alam & 1,3 & 8,2 \\
\hline - Kegagalan perjanjian outsourcing & 2,6 & 4,7 \\
\hline - Penerapan ketentuan baru & 2,1 & 5 \\
\hline - Kerusuhan dan unjuk rasa karyawan & 2,9 & 6,1 \\
\hline - Kegagalan utility service (misal: listrik padam) & 4,6 & 6,6 \\
\hline \multicolumn{3}{|l|}{ Risiko Hukum } \\
\hline - Penerapan ketentuan know-your-customer & 4,4 & 6,5 \\
\hline - Kerahasiaan bank & 8,0 & 3,2 \\
\hline - Penerapan ketentuan tentang perlindungan nasabah & 6,2 & 8,2 \\
\hline - Penerapan ketentuan perlindungan data & 4,0 & 8,0 \\
\hline Rata-rata & 4,5 & 6,3 \\
\hline
\end{tabular}




\section{Sistem Pengendalian Risiko Operasional pada Bank Perkreditan Rakyat dengan Pendekatan Indikator Dasar}

Sunarjo, Sari Yuniarti

tidak lengkap, perputaran karyawan yang tinggi, sengketa antar karyawan, terlalu tergantung pada karyawan tertentu, pengendalian perubahan data yang tidak memadai, gangguan pelayanan, baik gangguan sebagian atau seluruhnya, kegagalan perjanjian outsourcing penerapan ketentuan baru, dan kerusuhan dan unjuk rasa karyawan.

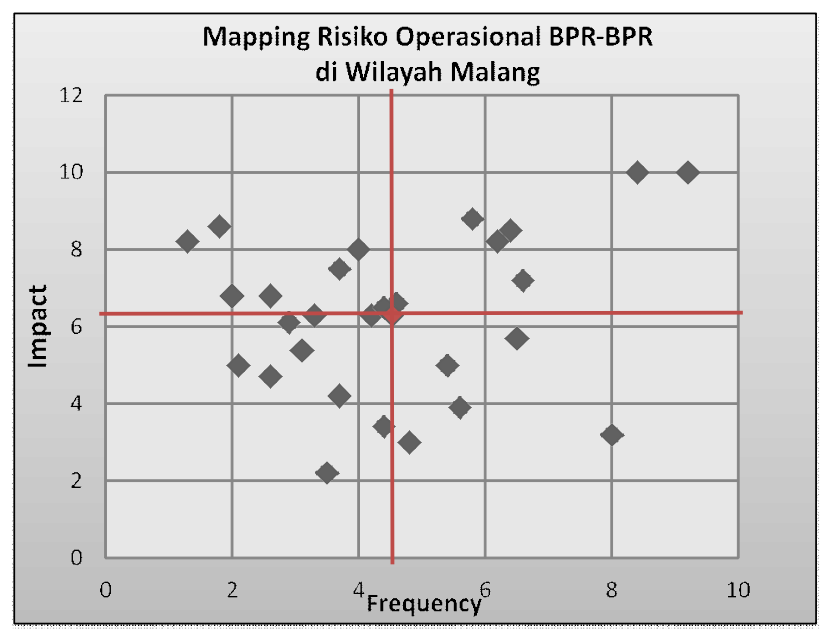

Gambar 1. Hasil Mapping Score Kejadian Risiko Operasional BPR-BPR di Wilayah Malang

Kuadran II berisi kejadian yang memiliki tingkat frekuensi terjadi risiko rendah dan tingkat impact yang tinggi, hal ini menunjukkan bahwa kejadian risiko operasional ini dinilai memberikan dampak kerugian yang besar tetapi tidak terlalu sering terjadi. Kejadian-kejadian yang termasuk dalam kuadran ini adalah: Iaporan keuangan yang tidak lengkap atau tidak benar, permasalahan kesehatan dan keselamatan kerja, pencurian dan penipuan dari luar, kebakaran, bencana al am, penerapan ketentuan know-your-customer, dan penerapan ketentuan perlindungan data.

Kuadran III berisi kejadian yang memiliki tingkat frekuensi terjadi risiko tinggi dan tingkat impact yang rendah, hal ini menunjukkan bahwa kejadian risiko operasional ini dinilai tidak terlalu memberikan dampak kerugian tetapi sering terjadi. Kejadian-kejadian yang termasuk dalam kuadran ini adalah: kelalaian petugas pemasaran, kesalahan dalam memberikan informasi, penipuan internal, datayang tidak lengkap (data corruption), dan kerahasiaan bank.

Kuadran IV berisi kejadian yang memiliki tingkat frekuensi terjadi risiko tinggi dan tingkat impact yang rendah, hal ini menunjukkan bahwa kejadian risiko operasional ini dinilai tidak terlalu memberikan dampak kerugian tetapi sering terjadi. Kejadian-kejadian yang termasuk dalam kuadran ini adalah: kesalahan melakukan transaksi, pengendalian intern yang lemah, praktek manajemen yang buruk, pelatihan karyawan yang tidak memadai, kesalahan input data (data entry errors), kegagalan utility service (misal: listrik padam), dan penerapan ketentuan tentang perlindungan nasabah.

\section{Hasil Perhitungan Capital Charge dengan Pendekatan Indikator Dasar}

Dasar perhitungan PID dengan menggunakan nilai gross income (laba bruto). Laba bruto didefinisikan sebagai pendapatan bunga bersih (pendapatan bunga dikurangi biaya bunga) ditambah pendapatan non-bunga bersih (pendapatan operasional di luar bunga dikurangi biaya di luar bunga).

Adapun besar laba bruto masing-masing BPR di wilayah Malang selama tahun 2013-2015 disajikan pada Tabel 2.

\section{PEMBAHASAN}

Berdasarkan hasil perhitungan capital charge dengan pendekatan indikator dasar. dapat diketahui capital chargedari masing-masing BPR memiliki jumlah masing-masing capital charge yang berbeda-beda, hal ini disebabkan kemampuan dalam mengelola operasional bank menghasilkan profit margin yang berbeda. Semakin besar gross income, maka capital charge yang digunakan untuk mengcover terjadinya risiko operasional akan semakin besar (Baud et al., 2002). Total capital chargeseluruh 
BPR di Wilayah Malang sebesar Rp4.085.114.000,00, hal ini menunjukkan besar jumlah capital charge yang digunakan untuk mengantisipasi terjadinya risiko operasional.

Pendekatan Indikator Dasar atau PID merupakan pendekatan yang paling sederhana dan tidak sensitif terhadap risiko sehingga akan menghasilkan beban modal yang cenderung besar. PID cocok digunakan oleh bank-bank yang lebih kecil dengan aktivitas bisnis yang sederhana seperti BPR. Untuk bank-bank yang aktif secara internasional, dan bank-bank yang memiliki risiko operasional tinggi didorong untuk menggunakan pendekatan yang lebih mendekati risiko sebenarnya. Dengan pendekatan indikator dasar, maka besarnya kemungkinan terjadi risiko operasional pada masingmasing BPR dapat diantisipasi dengan adanya capital charge, sehingga tidak mengganggu kecukupan permodalan (CAR) yang dihitung dari perbandingan modal inti dengan ATMR (Aktiva Tertimbang Menurut Risiko). Dalam PID, perhitungan ATMR untuk risiko operasional dalam perhitungan KPMM dapat dilakukan dengan rumus sebagai berikut: ATMR $=12,5 \% \times$ capital charge risiko operasional, sehingga pada BPR-BPR di Wilayah Malang besarnya ATMR risiko operasional:

$$
\begin{aligned}
\mathrm{ATMR} & =12,5 \% \times \mathrm{Rp} 4.085 .114 .000,00 \\
& =\mathrm{Rp} 510.639 .250,00
\end{aligned}
$$

Berdasarkan perhitungan diperoleh besar ATMR risiko operasional di BPR-BPR Wilayah Malang sebesar Rp510.639.250,00. Hal ini berarti bahwa tindakan mitigasi pada risiko operasional dengan menggunakan pendekatan PID menghasilkan besar ATMR sebesar Rp510.639.250,00. Hasil

\begin{tabular}{|c|c|c|c|c|c|}
\hline \multirow{2}{*}{ Nama BPR } & \multicolumn{3}{|c|}{ Tahun } & \multirow{2}{*}{ Jumlah } & \multirow{2}{*}{$\begin{array}{c}\text { Jumlah } \\
{ }^{*} 15 \% \\
\end{array}$} \\
\hline & 2013 & 2014 & 2015 & & \\
\hline PT BPR Tumpang Prima Artorejo & 757.611 & 457.821 & 409.698 & 541.710 & 81.257 \\
\hline PT BPR Adiartha Reksacitra & 1.692 .691 & 1.692 .691 & 1.617 .945 & 1.667 .776 & 250.166 \\
\hline PT BPR Pujon Jayamakmur & 630.164 & 800.810 & 616.976 & 682.650 & 102.398 \\
\hline PT BPR Kimisanda & 1.661 .475 & 1.445 .509 & 1.016 .042 & 1.374.342 & 206.151 \\
\hline PT BPR Mitra Catur Mandiri & 1.147 .598 & 1.299 .353 & 1.759 .586 & 1.402 .179 & 210.327 \\
\hline PT BPR Citra Halim Perdana & 246.273 & 78.175 & 477.047 & 267.165 & 40.075 \\
\hline PT BPR Delta Artha Kencana & 100.856 & 182.647 & 296.713 & 193.405 & 29.011 \\
\hline PT BPR Delta Singosari & 214.315 & 223.172 & 95.026 & 177.504 & 26.626 \\
\hline PT BPR Kridadhana Citranusa & 1.483 .433 & 1.366 .702 & 1.046 .799 & 1.298 .978 & 194.847 \\
\hline PT BPR Surya Abadi Bersaudara & 658.367 & 831.536 & 397.678 & 629.194 & 94.379 \\
\hline PT BPR Dhana Lestari & 1.293 .452 & 2.568 .441 & 3.602 .798 & 2.488 .230 & 373.235 \\
\hline PT BPR Artha Wiwaha Arjuna & 1.067 .778 & 1.035 .331 & 912.248 & 1.005.119 & 150.768 \\
\hline PT BPR Kerta Arthamandiri & 3.416 .968 & 3.005 .646 & 2.250 .122 & 2.890 .912 & 433.637 \\
\hline PT BPR Eka Dana Mandiri & 413.171 & 263.284 & 212.602 & 296.352 & 44.453 \\
\hline PT BPR Eka Dana Utama & 536.445 & 370.595 & 562.233 & 489.758 & 73.464 \\
\hline PT BPR Dau Lestari & 332.683 & 312.302 & 246.771 & 297.252 & 44.588 \\
\hline PT BPR Trikarya Waranugraha & 3.167 .881 & 2.025.717 & 1.843 .254 & 2.345.617 & 351.843 \\
\hline PT BPR Sumber Arto & 657.346 & 584.420 & 466.290 & 569.352 & 85.403 \\
\hline PT BPR Gunung Ringgit & 2.880 .434 & 917.858 & 1.512 .659 & 1.770 .317 & 265.548 \\
\hline PT BPR Armindo Kencana & 7.446 .112 & 6.816 .861 & 6.275 .873 & 6.846 .282 & 1.026 .942 \\
\hline \multicolumn{5}{|c|}{ Total Capital Charge } & 4.085.114 \\
\hline
\end{tabular}

Tabel 2. Besar Laba Bruto pada BPR-BPR di Wilayah Malang Tahun 2013-2015 (Dalam Ribuan Rupiah)

Sumber data: Publikasi Laporan Keuangan BPR (Bank Indonesia, 2015). 
perhitungan ini dapat digunakan sebagai dasar penentuan dalam melakukan tindakan mitigasi risiko operasional di masa yang akan datang. Kelebihan dari pendekatan PID ini adalah mudah untuk diimplementasikan. Tidak membutuhkan waktu dan sumber daya yang besar seperti kalau bank mengembangkan model yang lebih maju. Cocok bagi bank yang sedang dalam tahap awal melakukan implementasi Basel II, khususnya ketika data kerugian belum mencukupi untuk membuat model yang lebih kompleks dan cocok bagi bank dengan ukuran kecil dan menengah.

Namun demikian, metode PID memiliki kelemahan yaitu tidak memberikan perhatian khusus terhadap eksposur dan pengendalian risiko operasional bank, struktur aktivitas bisnis, peringkat kredit, dan indikator lainnya (ChavezDemoulin et al., 2006).

\section{SIMPULAN DAN SARAN}

\section{Simpulan}

Penelitian ini bertujuan untuk mengukur dampak kerugian yang ditimbulkan akibat adanya risiko operasional dan mengidentifikasi sistem pengendalian risiko operasional dengan menggunakan pendekatan indikator dasar. Risiko operasional terdiri dari risiko proses internal, risiko manusia, risiko sistem, risiko ekternal, dan risiko hukum. Hasil penelitian menunjukkan kejadian risiko operasioal terbagi dalam 4 kuadran yaitu: (1) Low Frequency/High Impact (LFHI); (2) High Frequency/High Impact (HFHI); (3) Low Frequency/Low Impact (LFLI); dan (4) High Frequency/Low Impact (HFLI). Pembagian kuadran tersebut menghasilkan informasi yang terkait dengan bagaimana risiko operasional akan dikelola.

Berdasarkan hasil perhitungan capital charge dengan pendekatan indikator dasar. dapat diketahui capital charge dari masing-masing BPR memiliki jumlah masing-masing capital charge yang berbedabeda, hal ini disebabkan kemampuan dalam mengelola operasional bank menghasilkan profit margin yang berbeda. Semakin besar gross income, maka capital charge yang digunakan untuk mengcover terjadinya risiko operasional akan semakin besar. Total capital charge seluruh BPR di Wilayah Malang sebesar Rp4.085.114.000,00, sedangkan perhitungan ATMR diperoleh Rp510.639.250,00 hal ini menunjukkan besar jumlah capital charge dan ATMR yang digunakan untuk mengantisipasi terjadinya risiko operasional.

\section{Saran}

Bagi BPR, hendaknya perlu ditingkatkan tindakan preventif dalam mengantisipasi kejadian risiko operasional melalui peningkatan kemampuan SDM, pengaturan sistem operasional BPR yang lebih baik, pengawasan dan pengendalian manajemen yang memadai dan melakukan tindak evaluasi terhadap penyimpangan yang terjadi.

Bagi pengembangan ilmu, bahwa sistem pengendalian risiko operasional dengan pendekatan indikator dasar adalah fit untuk mengukur besarnya risiko operasional pada BPR, sehingga perhitungan capital charge dan ATMR diharapkan dapat menjadi informasi yang benar untuk mengantisipasi risiko operasional yang mungkin terjadi di masa yang akan datang.

Bagi peneliti selanjutnya, sebaiknya dapat mengembangkan pengukuran yang lebih komprehensif dengan menggunakan Standardized Approach atau Advanced Measurement Approach mengingat Basic Indicator Approach memiliki kelemahan yaitu tidak memberikan perhatian khusus terhadap eksposur dan pengendalian risiko operasional bank, struktur aktivitas bisnis, peringkat kredit, dan indikator lainnya. Penelitian sejenis juga bisa dilakukan pada bank-bank umum di Indonesia. 


\section{Jurnal Keuangan dan Perbankan | PERBANKAN}

Vol. 21, No.1, Januari 2017: 96- 104

\section{DAFTAR PUSTAKA}

Basel Committee on Banking Supervision. 2004. Basel II: International Convergence of Capital Measurement and Capital Standards - A Revised Framework. Basel Committee Publications No.107. Bank for International Settlements.

Bank Indonesia. 2012. Consultative Paper Basel III: Global Regulatory Framework for More Resilient Banks and Banking Systems. Departemen Penelitian dan Pengaturan Perbankan Indonesia.

Bhatia, M. 2002. New Basel Accord: Operational Risk Management-Emerging Frontiers for the Profession. ISACA Journal, 1.

Baud, N., Frachot, A., Roncalli, T. 2002. How to Avoid Over-estimating Capital Charge for Operational Risk? Working Paper. Crédit Lyonnais, Groupe de Recherche Opérationnelle.

Chavez-Demoulin, V., Embrechts, P., Nešlehová, J. 2006. Quantitative Models for Operational Risk: Extremes, Dependence and Aggregation, Journal of Banking and Finance, 30(10): 2635 - 2658.

Ebnöther, S., Vanini, P., Mc Neil, A., \& Antolinez-Fehr, P. 2001. Modelling Operational Risk. Journal of Risk, 5(3): 1-16.

Hawke, J.D. Jr. 2002. The New Basel Capital Accord: A Status Report. Institute of International Bankers, Washington, D.C.
Lenzmann, B., Ritchie, M., Nardin, D., \& Law, C. 2005. Managing Operational Risk - Beyond Basel II. KMPG International Swiss.

Moosa, I., 2011. Operational Risk as a Function of the State of the Economy. Economic Modelling, 28(5): 2137-2142.

Scandizzo, S. 2005. Risk Mapping and Key Risk Indicators in Operational Risk Management. Econ Notes, 34: 231-256.

Sundmacher, M. 2007. The Basic Indicator Approach and the Standardised Approach to Operational Risk: An Example and Case Study Based Analysis. Working Paper, University of Western Sydney.

Otoritas Jasa Keuangan. 2015. Peraturan Otoritas Jasa Keuangan Nomor 13/POJK.03/2015 tentang Penerapan Manajemen Risiko BPR. http://www.ojk.go.id/ id/kanal/perbankan/regulasi/peraturan-ojk/ Pages / POJK-Nomor-13-POJK-03-2015Penerapan-Manajemen-Risiko-BPR.aspx \#sthash.tAEMKW7m.dpuf. Diakses tanggal 28 Oktober 2015.

Pyle, D.H. 1997. Bank Risk Management: Theory. Working Paper. Research Program in Finance. UC Berkeley. 